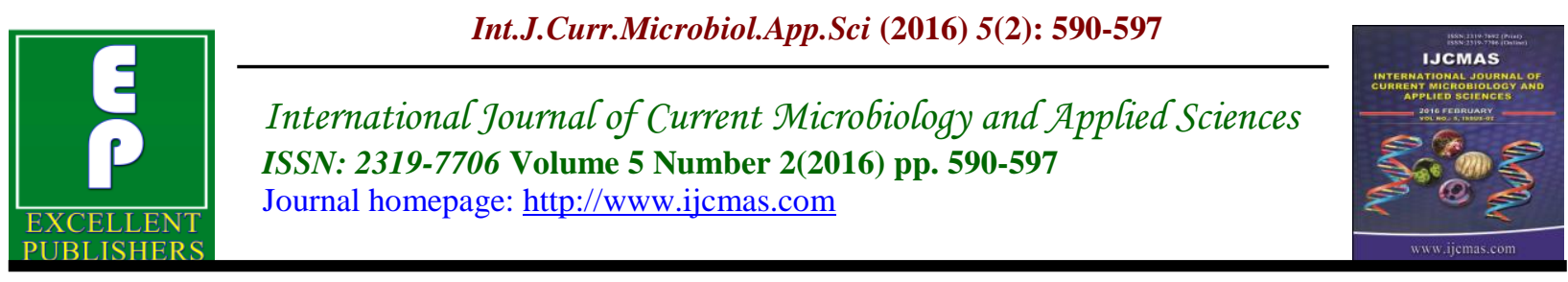

Original Research Article

doi: http://dx.doi.org/10.20546/ijcmas.2016.502.066

\title{
Rust Disease of Frangipani (Plumeria) Caused by Coleosporium sp. in Gurgaon, Haryana, India
}

\author{
Narendra Kumar* and S.M.Paul Khurana \\ Amity Institute of Biotechnology, Amity University Haryana, Manesar-122413, \\ Gurgaon, Haryana (India) \\ *Corresponding author
}

\begin{abstract}
A B S T R A C T
Keywords

Frangipani

(plumeria),

Coleosporium sp,

Urediniospores,

Rust.

Article Info

Accepted:

28 January 2016

Available Online:

10, February 2016

Plumeria (common name Frangipani) is a genus of flowering plants in the dogbane family, Apocynaceae., planted commonly on roadsides, gardens in most of the places of Gurgaon, Haryana for its beautiful fragrant flowers. A survey of young plantations of various regions of Gurgaon revealed that this plant was seriously infected by a rust fungus Coleosporium sp, which later leading to drying and death of the foliage. The infected leaves show numerous tiny, raised, bright orange yellow, rusty pustules on the adaxial (upper)surface of the leaf thus reducing the available photosynthetic area of the leaf. The diameter of most of the rust pustules ranged between 0.5-3.0 mm. Symptoms were absent in the stem or flowers. Microscopic studies indicated the presence of uredium, formed from the extending mycelium in a crosswise direction and emerged through ruptured lower epidermis. No other fruiting structures, telium, aecium or spermatium were found to be present. Both mature and young leaves were found to get equally infected by the pathogen. Severe infection of rust often resulted in chlorosis, necrosis and premature leaf fall. This rust is reported for the first time from Gurgaon region of Haryana state.
\end{abstract}

\section{Introduction}

Frangipani is a popular landscape plant and is important to the garden/ornamental nursery. It is widely grown on farms and in various public and private settings. Frangipanis are useful in providing shade and flowers in summer showing a volatile nature of fragrance. The trees have been cultivated in Asia for over 200 years, not only for the fragrant flowers, but also for the alleged medicinal properties of their milky sap (Menninger, 1962). These plants are propagated vegetatively by stem cuttings.
The flowers have a sweet odour and are employed for the preparation of garlands and perfumes and frequently utilized in making leis.

They grow as small ornamental trees in temple premises, parks and residential and commercial landscapes in Haryana State. The plant is important to India's religious worship in temples, floriculture and nursery industries. It is widely grown on temples, farms and in various public and private 
settings either as a specimen ornamental, for shade, or in plant groupings (Zahid et al. 2010). A disease called plumeria rust, associated by the fungus Coleosporium plumeriae, is now a firmly established and is a serious problem detracting from their value (To-anun et al., 2004; Hernandes et al., 2005 ;Chung et al., 2006; Baiswar et al., 2008; Holcomb \& Aime, 2010 and Wang et al.,2011). This rust fungus does not have any other known hosts other than frangipani. The disease is spread by windborne spores and human movement of plants.

Since no work has been done regarding rust infection on Plumeria plants in Gurgaon region. Therefore a survey for rust infection was conducted at Gurgaon region,infected samples were brought to the laboratory.

\section{Materials and Methods}

Infected plant materials of Plumeria were collected from different parts of Gurgaon,Haryana State during March 2014 to March 2015. Both infected and healthy leaves of Plumeria were collected from plants belonging to P.obtusa and $P$. hybrida. Infected plant parts were noticed carefully in the field, field notes made regarding their way of infection,nature of colonies, pathogenicity, locality, etc. In the field, each infected plants were collected separately in polyethylene bags. Leaf materials were collected as whole twigs and individual leaves of different maturity stages were observed.

\section{Microscopic Studies}

Leaves with different stages of the disease were examined visually and under microscope and symptoms were observed.The scrapings were taken from infected areas and observed under the low high power of microscope. The length and breadth of 100 randomly selected urediniospores each from P.obtusa and $P$. hybrida were recorded. For examination of the development of the fungus within the leaf tissue, hand sections were taken across diseased sites of the leaves and studied under microscope.

\section{Disease Symptoms}

The diameter of 400 randomly selected rust pustules, 200 from young leaves and 200 from old leaves, each of P. obtusa and $P$. hybrida was measured, using a millimeter scale. The growth stage at which the leaf becomes susceptible to rust infection was also studied on 200 twigs each from P.obtusa and P. hybrida that consisted of right from young buds to mature leaves.

\section{Culture Trials}

In order to culture this rust PDA Medium was prepared.Freshly collected infected leaves portion was cut into $5 \mathrm{~mm}$ size and kept for growth of rust fungus.

\section{Pathogenicity}

Pathogenicity was tried by spraying urediniospores (prepared by dissolving one $5 \mathrm{~mm}$ diameter of rust pustule in $100 \mathrm{ml}$ double distilled water) on three healthy plumeria plants separately.Plants were kept under regular observation upto 25 days.

\section{Results and Discussion}

A survey of young Plantations of Plumeria obtusa and $P$. hybrida done at various places of Gurgaon from March,2014 to March,2015 plants revealed that they were heavily infected with rust. The first observable symptoms were small, bright orange yellow spots on the (adaxial) upper surfaces of the leaves (Figure 1). The rust 
symptoms on both Plumeria species were found similar.

The upper sides of infected leaves showed numerous tiny, raised, bright orange yellow, powdery rust pustules (uredinia) (Figure 2). The diameter of most of the rust pustules ranged between $0.5-3.0 \mathrm{~mm}$ (Table 1). It was observed that the pustule did not expand noticeably with the maturity of the leaf, however, when there was severe infection, 1--3 pustules tended to coalesce(Figure 3 ).

The pustules found to emerge sparsely on the upper surface of heavily diseased leaves. The twigs were further examined to determine the progression of symptoms during maturation of the leaves.The pathogen however was not seen or recorded on stems and flowers.It was observed that as lesions age increases,gets enlarged and coalesce, these yellow areas develop into sunken, angular and grayish to brown spots and turned into brown, necrotic areas(Figure 4).

Uredinia were numerous, mostly hypophyllous and yellowish orange. Urediniospores were catenulate, verrucose, orange en masse, globose, ovoid, angular or ellipsoidal, and measured 18.9 to $40.3 \times$ 15.4 to $31.9 \mu \mathrm{m}$ (Figure 5,6). The rust was identified as Coleosporium sp.The other fruiting structures viz.,, telium, aecium or spermatium were not found to be present.

This can systematically placed in classUredinomycetes, order-Uredinales and family Coleosporaceae and identified as Coleosporium sp.

These morphological characteristics agree with those of Coleosporium plumeriae Pat. except telia that were not found to be present in these samples (Traquair and Kokko, 1980). It can be seen on Fig.7 that the lower epidermis cell has been disintegrated due to the pressure exerted by the growing fungal structure. Severely diseased leaves became dry, curled, distorted, and fallen down from the plant. Premature defoliation was noted to approach about 90-100 per cent.

Both mature and young leaves were found to be equally susceptible to the pathogen. The apical bud showed absence of rust infection in both species. The apical bud found to contain more latex compared to mature leaves, this may be due inhibitory action of latex against germination of urediniospores. It was observed that while the lesions can develop anywhere on the upper surface of leaf but they tend to be concentrated around the margins, where dew and rain droplets collect. During frequent visit for plumeria plants at Gurgaon region it was observed that in early in the season the first lesions usually appear on the lowermost leaves and the infection slowly progresses upward in the tree. The infected leaves of plumeria drop before maturation, leaving long expanses of twigs devoid of leaves.

On microscopic examination abnormally yellow colour of plant tissues was observed resulting from partial failure to develop chlorophyll. Thus leaving large portions of the leaf unable to photosynthesize, reducing the plant's ability to manufacture food. As disease progresses, the spots got enlarged and merged to form sunken brown spots. Lastly infected leaves curled and eventually drop off. There was premature death of cells in living tissue causing necrosis. The overall fungal infection showed the shedding of various parts such as a plant dropping a leaf, fruit, flower, or seed. Thus this rust caused leaf chlorosis, necrosis and premature leaf fall. During the study a negative impacts on flower production was observed. 
The fungus did not grow on PDA medium. Thus fungus is an obligate parasite. During infection time, the temperature range of Gurgaon, Haryana state was in between 8 and $20^{\circ} \mathrm{C}$.

Typical rust symptoms got developed in 15 days on all spray inoculated leaves while noninoculated leaves remained healthy. After 25 days of interval similar uridiniospores development was recorded. Characteristics and spore measurements matched those of the rust from original infected plants

Table.1 Average Diameter of Rust Pustules on Young and Old Leaves of P. obtusa and $P$. hybrida

\begin{tabular}{|c|c|c|}
\hline Species & Stage of leaf & Average diameter of a rust pustule $(\mathrm{mm})$ \\
\hline \multirow[t]{2}{*}{ Plumeria obtusa } & Young & Young $0.5 \pm 0.1$ \\
\hline & Old & Old $1.7 \pm 2.8$ \\
\hline \multirow[t]{2}{*}{ Plumeria hybrida } & Young & Young $0.5 \pm 0.1$ \\
\hline & Old & Old $2.0 \pm 3.0$ \\
\hline
\end{tabular}

Figure.1Rust Infection in Young Plantation of Plumeria Plants

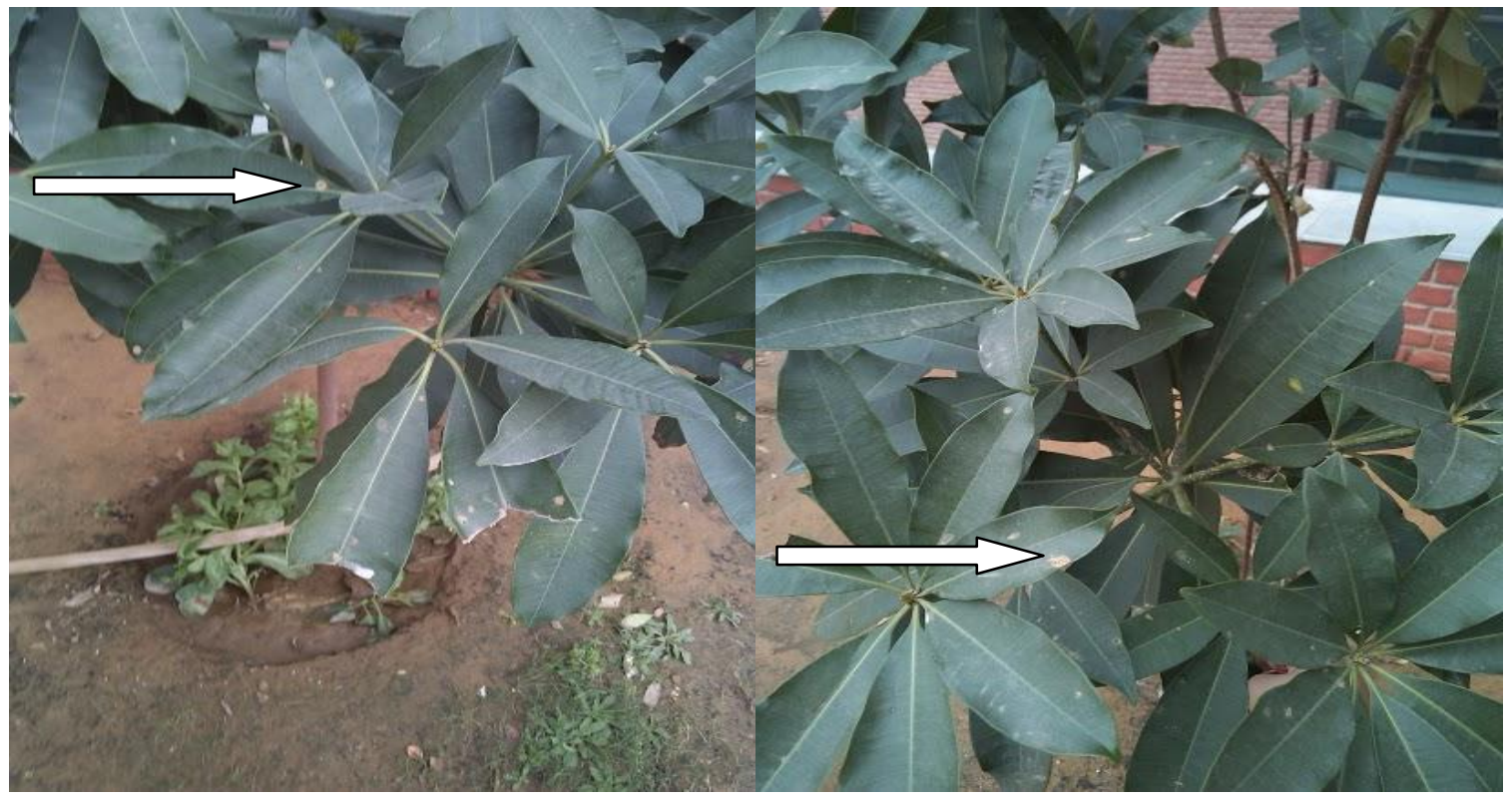


Figure.2 Enlarged View of Rust Infection

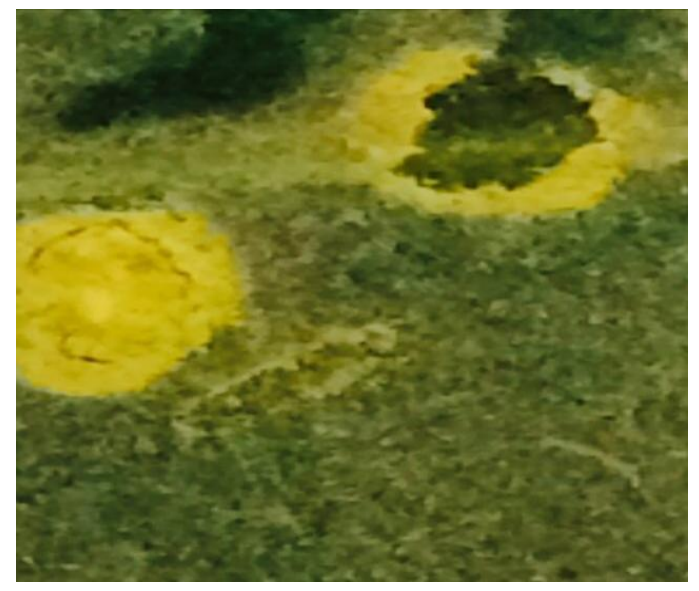

Figure.3 1-3 Pustules Tended to Coalesce

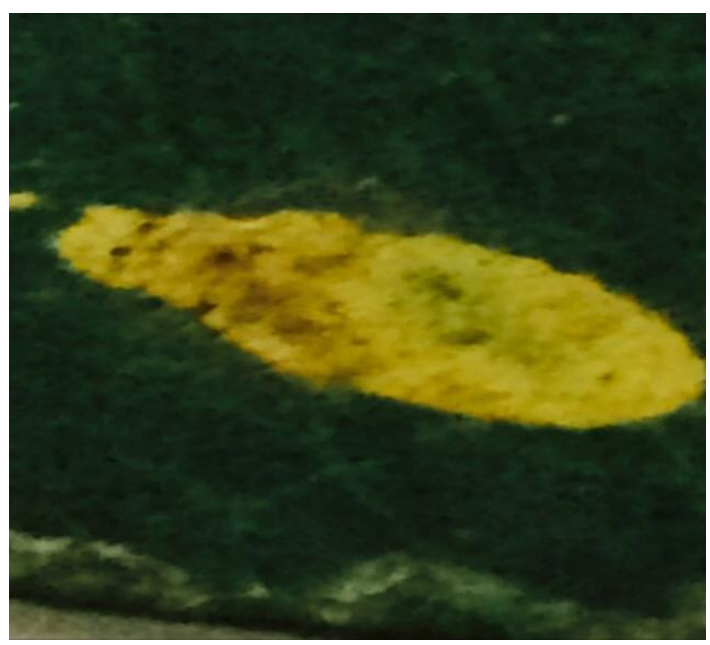

Figure.4 Various Shapes of Pustules on Leaf of Plumeria

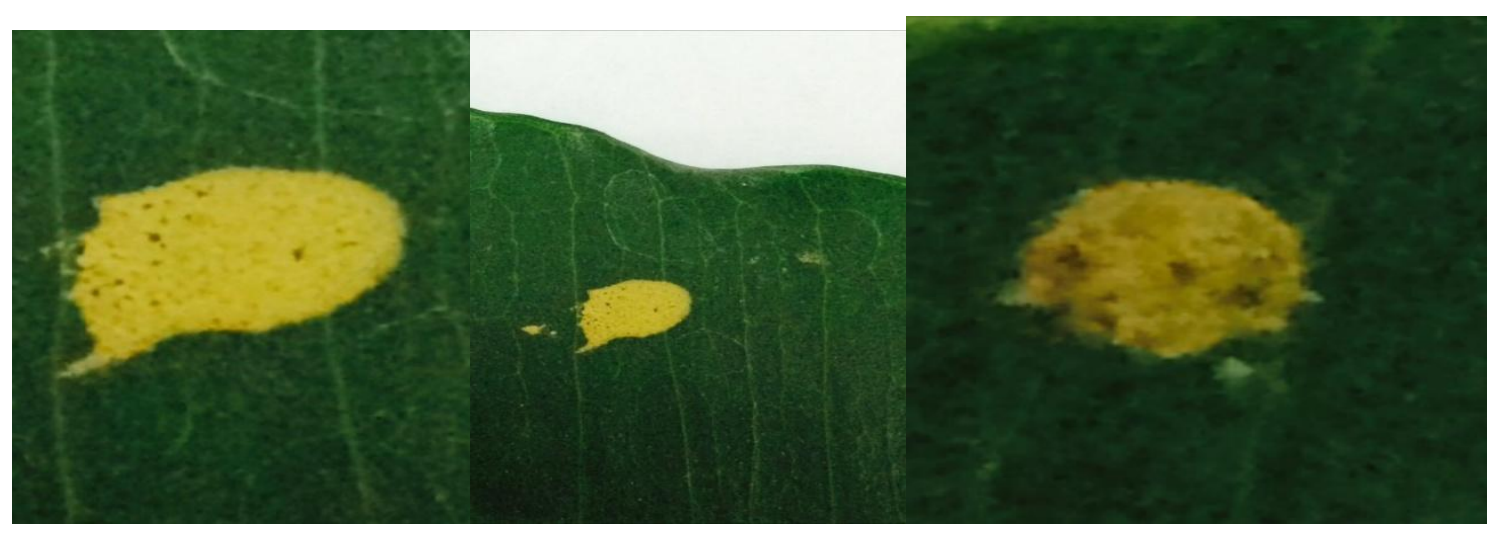


Int.J.Curr.Microbiol.App.Sci (2016) 5(2): 590-597

Figure.5 Scrapped Rust Urediniospores At 10x

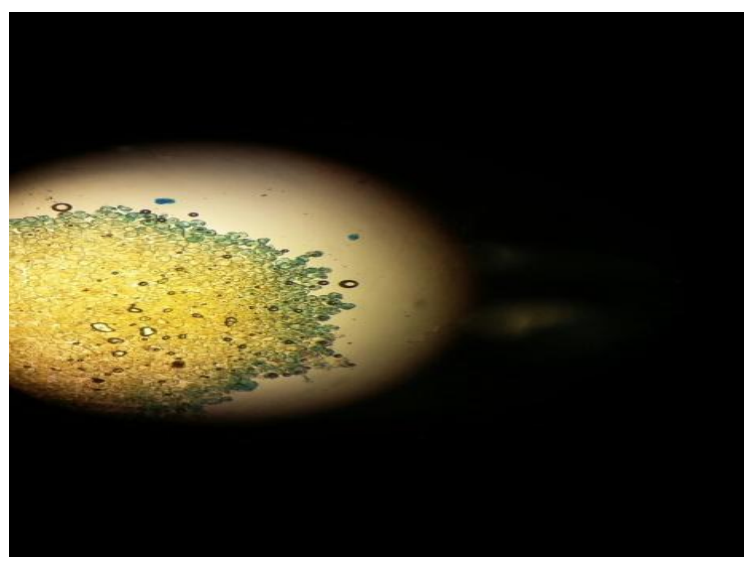

Figure.6 Scrapped Rust Urediniospores at 40x

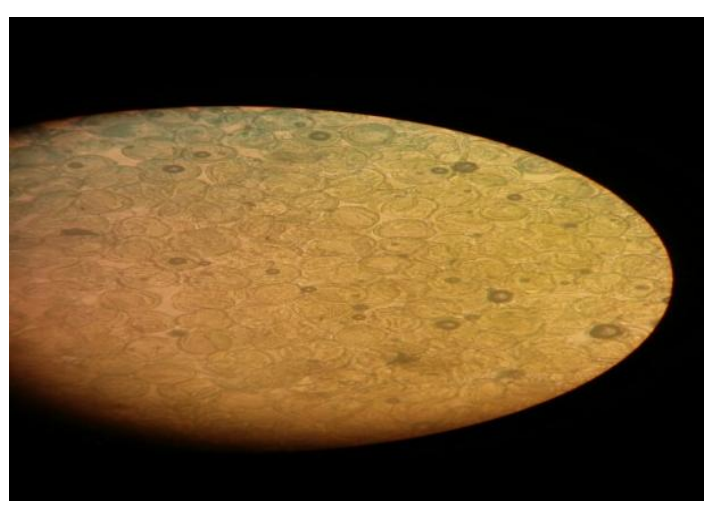

Figure.7 Urediniospores Emergence of Coleosporium Sp Along with Hyphae

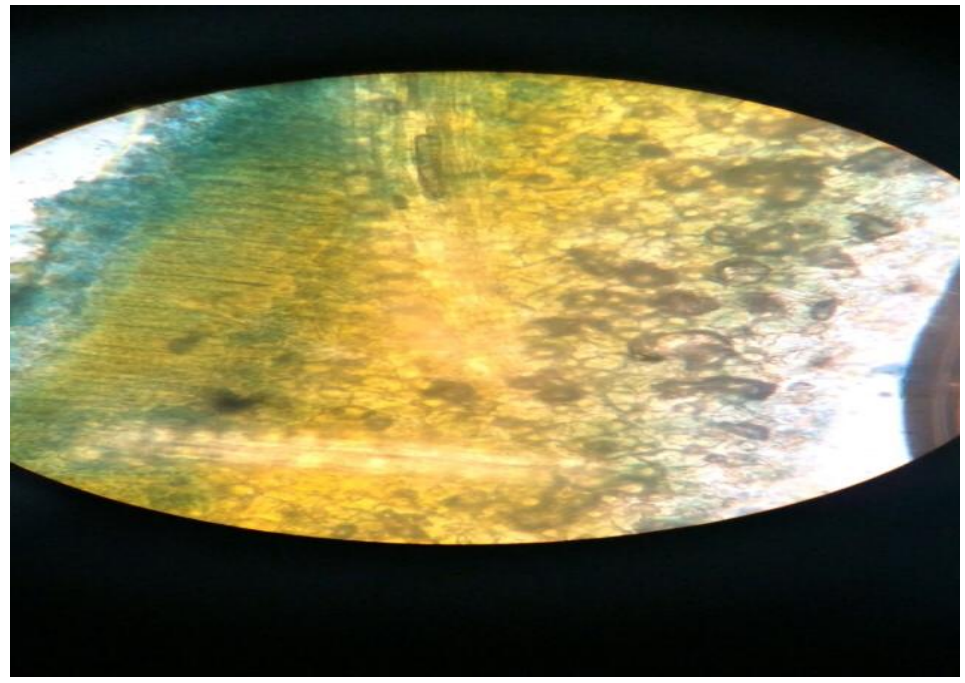


To-anun et al.( 2004) stated that this rust fungus was originally reported in Santo Domingo of West Indies, from more than 150 years ago but its distribution was limited to tropical and subtropical areas of America (mostly Central America) until the 1980s. The leaf rust disease in Plumeria first appeared in Sri Lanka some time in the year 2002 and is now worldwide. The disease is found in both Plumeria rubra and Plumeria obtusa (Apocynaceae sp.,) and the infected leaves show numerous tiny, raised, orange coloured rusty pustules on the abaxial surface of the leaf (Weeraratne and Adikaram, 2006).

But in present investigation rust symptoms were observed on adaxial surface of leaves of Plumeria obtusa and P. hybrida.From Taiwan, Chung et al (2005) reported that Plumeria (Frangipani) rust disease was caused by Coleosporium plumeriae. Holcomb and Aime (2010) recorded the first report of plumeria rust from Louisiana and Malaysia and of susceptibility of another member of the Apocynaceae, Madagascar periwinkle to $C$. plumeriae. A survey of five Baton Rouge retail nurseries in September 2009 revealed that $87 \%$ (90 of 103) of the plumeria plants were heavily infected with rust followed by leaf chlorosis, necrosis, and abscission. In present investigation we observed rust pustules size ranging between 0.5-3.0 $\mathrm{mm}$.

In Australia, the disease is most noticeable in late summer and autumn (Burkey's Backyard, 2006). In present investigation this rust was observed in autumn period at Gurgaon region of Haryana. In general, rust is rather specific in its host range. The spores produced in these pustules are carried by splashing rain or air currents to near-by healthy plants where new infections will occur. Anders (2001) reported that Rust Fungus does not kill frangipanis, but can rapidly de-foliate an entire tree.During present investigation enough defoliation was observed. Hosagoudar and Archana (2011) found Coleosporium plumeriae infection causing drying and death of foliage temple tree at Kerala. However, as for our knowledge this is the first report of this rust fungus from Gurgaon region. Therefore, fungicidal control for this rust is very important.

Hosagoudar (1988) stated that most infections are caused by windborne urediniospores that stick to moist leaves under wet or humid conditions. The climate in Haryana State is most suited for the disease infection and spread. Spores germinate on plumeria leaves, penetrate the surface, and grow as fungal hyphae forms mycelial mats that infect cells inside the leaf forming internal blockage.Prominent and sucessful infections erupt back through the epidermis to create uredinial sori full of powdery spores that are dispersed to new infection sites on the same or other leaves of plumeria species. During present investigation the pathogen showed his survival on infected leaves and leaf debris. So in this way Coleosporium sp adapts to changing environmental conditions by producing more distinct and fit progeny through process of reproduction.

The rust caused by Coleosporium sp in frangipani was at uredinial stage where the fungus produces urediniospores (dikaryotic). Urediniospores showed arising from the lower surface of frangipani leaves. The other fruiting structures like telium, aecium or spermatium were not found to be present. Both mature and young leaves were found to be equally susceptible to the pathogen. The apical bud showed absence of rust infection. Severe infection of rust often resulted in chlorosis, necrosis and premature leaf fall. 


\section{References}

Anders, M. (2001).Plumeria 101. Rust fungus (Coleosporium plumierae), problems and solutions. http://www.plumeria101.com/proble $\mathrm{ms} /$ rust.html.

Baiswar P, Chandra S, Kumar R, (2008).First report of rust caused by Coleosporium plumeriae on Plumeria alba in India. Plant Pathology 57, 787.

Burkey'sBackyard.(2006).Frangipanis. http:/ /www.burkesbackyard.co.au. Chung WH, Abe JP, Yamaoka Y, Haung JW, Kakishima M, (2006). First report of plumeria rust disease caused by Coleosporium plumeriae in Taiwan. Plant Pathology 55, 306.

Hernández JR, Eboh DO, Rossman AY, (2005). New reports of rust fungi (Uredinales) from Nigeria. Caldasia 27, 213-221.

Holcomb GE, Aime MC, (2010). First report of Plumeria spp. rust caused by Coleopsporium plumeriae in Louisiana and Malaysia and Catheranthus roseus, a new host of this rust. Plant Disease 94, 272.

Hosagoudar V B. (1988). Uredinales of Kerala. J. Econ. Taxon. Bot. 12: 265272.

Hosagoudar V.B and Archana G.R(2011)Rust fungus on temple tree in Kerala India.Bioscience
Discovery 2(3),243-344.

Menninger, E. A. (1962). Flowering trees of the world. Hearthside Press Inc., New York. 336 p.

Traquair JA, Kokko EG, (1980). Spore morphology in Coleosporium plumeriae. Canadian Journal of Botany 58, 2454-2458.

To-anun C, Visarathanonth N, Engkhaninun J, Kakishima M, (2004). First report of plumeria rust, caused by Coleosporium plumeriae in Thailand. Natural History Journal of ChulalongkornUniversity 4, 41-46.

Wang Q, Thu PQ, Kakishima M, (2011). First report of a rust disease of Plumeria caused by Coleosporium plumeriae in Southern China and Vietnam. New Disease Reports 23, 10.

Weeraratne, T. P.; Adikaram, N. K. B. (2006).Biology of Plumeria leaf rust disease caused by Coleosporium plumeriae.Ceylon Journal of Science, Biological Sciences. 35 ( 2), 157-162.

Zahid Zaheer, Konale AG, Patel KA, Subur Khan W and Farooqui MN.(2010). Plumeria rubra Linn. : an Indian medicinal plant. International Journal of Pharmacy \& Therapeutics $1(2), 116-119$

\section{How to cite this article:}

Narendra Kumar and Paul Khurana, S.M. 2016. Rust Disease of Frangipani (Plumeria) Caused by Coleosporium sp. in Gurgaon, Haryana, India. Int.J.Curr.Microbiol.App.Sci. 5(2): 590-597. doi: http://dx.doi.org/10.20546/ijcmas.2016.502.066 